$14^{\text {th }}$ Conf. Agric. Develop. Res., Fac. of Agric.,

Ain Shams Univ., March, 2019, Cairo, Egypt

Special Issue, 27(1), 579 - 584, 2019

Website: http://strategy-plan.asu.edu.eg/AUJASCI/

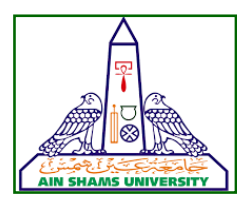

\title{
DEVELOPMENT OF SOME TOLERANT YEAST (SACCHAROMYCES CEREVISIAE) STRAINS TO HEAT AND SALT STRESSES
}

\author{
Sara K. Abd El-Maksoud ", Lamyaa M. Sayed, Fatma M. Badawy \\ and Eman M. Fahmy \\ Genetics Dept., Fac. of Agric., Ain Shams Univ., P.O. Box 68, Hadyek Shoubra11241, \\ Cairo, Egypt \\ *Corresponding author: sara_kamal2012@yahoo.com
}

Received 21 October , 2018, $\quad$ Accepted 30 October, 2018

\begin{abstract}
All living organisms are subjected to changing in conservational conditions, to which they must adapt to. Stress is defined as a threat refers to the physiological balance of systems critical to survival organisms. Five yeast strains (Saccharomyces cerevisiae) were subjected to different adverse environmental situations, such as thermal, osmotic and oxidative (salt) stresses. The objective of this work was to detect the most tolerant yeast strains under salt or heat stresses. Five yeast strains were exposed in a first experiment to heat stress at $20^{\circ} \mathrm{C}$ or $40^{\circ} \mathrm{C}$ beside to the control at $30^{\circ} \mathrm{C}$ to detect the more tolerant strain. The same yeast strains were subjected in a second experiment to two different concentrations of salt stress $(\mathrm{NaCl})$; 0.5 or $1.0 \mathrm{M}$, separately, for two days (at $30^{\circ} \mathrm{C}$ as normal temperature for growth), other strains were exposed to $0.5 \mathrm{M}$ concentration of $\mathrm{NaCl}$ for 24 hours, then $1 \mathrm{M}$ for another 24 hours. For the heat stress results, strain S4 was more tolerant at $40^{\circ} \mathrm{C}$ with insignificant difference compared to the control $\left(30^{\circ} \mathrm{C}\right)$, while it showed significant difference at $20^{\circ} \mathrm{C}$. Strain S5 also was more tolerant at $20^{\circ} \mathrm{C}$ with insignificant difference compared to the control. For salt treatment, the only insignificant value was for strain $\mathrm{S} 3$ at $0.5 \mathrm{M} \mathrm{NaCl}$ compared with the control.
\end{abstract}

Key words: Yeast, Saccharomyces cerevisiae, Stress response, Heat stress, Salt stress.

\section{INTRODUCTION}

Yeast (Saccharomyces cerevisiae) strains have been extensively studied in recent years for fuel ethanol production, in which yeast cells are exposed to various stresses such as high temperature, ethanol inhibition, and osmotic pressure from product and substrate sugars as well as the inhibitory substances released from the pre-treatment of biomass. An in-depth understanding of the mechanism of yeast stress tolerance contributes to breeding and gave more robust strains for ethanol production, especially under very high gravity conditions (Zhao and Bai, 2009). Organisms are continually challenged by changing environments. They have evolved physiological adaptations to cope with such change. These mechanisms include genome-scale gene expression changes on short, physiological time scales. Such changes have been most thoroughly studied in stressful environments, such as heat, cold, osmotic stress, salt, drought, gene-toxic stress, ultraviolet light, oxidative stress, wounding, and pathogen infection (Gasch et al 2000 and Jozefczuk et al 2010). Two types of stress response have been observed, one corresponding to a specific response involving genes with functions related to the tested stress, and the other to a more general response observed regardless of the type of stress involved (Brion, 2016). The objective of this study was to detect the most tolerant yeast strains exposed to heat or salt stress. 


\section{MATERIALS AND METHODS}

\section{Materials}

\section{Yeast strains}

Five yeast strains were used in this study, their names, codes and sources are shown in Table 1.

Table 1. Names, codes and sources of the five yeast strains (Saccharomyces cerevisiae)

\begin{tabular}{|c|c|c|}
\hline $\begin{array}{c}\text { Yeast } \\
\text { strains name }\end{array}$ & Code & Source \\
\hline UQM-49 & S1 & $\begin{array}{l}\text { Microbial Resources center (Cairo } \\
\text { MIRCEN) }\end{array}$ \\
\hline $\begin{array}{l}\text { NRRLY- } \\
17008\end{array}$ & S2 & $\begin{array}{l}\text { Microbial Resources center (Cairo } \\
\text { MIRCEN) }\end{array}$ \\
\hline LBC-1208 & S3 & $\begin{array}{l}\text { Microbial Resources center (Cairo } \\
\text { MIRCEN) }\end{array}$ \\
\hline LBC-254 & S4 & $\begin{array}{l}\text { Microbial Resources center (Cairo } \\
\text { MIRCEN) }\end{array}$ \\
\hline ATCC-58523 & S5 & $\begin{array}{l}\text { Dr. Mohamed Adel, Food Science } \\
\text { Dept., Fac. of Agriculture, Ain } \\
\text { Shams University. }\end{array}$ \\
\hline
\end{tabular}

\section{YPG medium}

Yeast peptone glucose (YPG) medium was used according to Curran and Bugeja (2006). The standard YPG medium consisting of $1 \%$ yeast extract, $2 \%$ peptone, $2 \%$ glucose and $2 \%$ agar routinely used for maintenance and preparation of cultures for yeast experiments.

\section{Methods}

\section{Yeast stress experiments}

\subsection{Heat stress}

Heat stress was performed at $20^{\circ} \mathrm{C}$ and $40^{\circ} \mathrm{Cin}$ YPG broth culture for 2 days compared with the control at $30^{\circ} \mathrm{C}$. The strains were grown over night at $30^{\circ} \mathrm{C}$, then in the next day at $20^{\circ} \mathrm{C}$ overnight again and the strains were grown overnight at $30^{\circ} \mathrm{C}$ and the next day at $40^{\circ} \mathrm{C}$ overnight using Gasch (2000) method.

\subsection{Salt stress}

Salt stress was applied using two concentrations; $(0.5 \mathrm{M} \mathrm{NaCl} ; 2.9 \mathrm{gm}$ up to $100 \mathrm{ml}$ YPG medi- um, $1 \mathrm{M} \mathrm{NaCl} ; 5.8 \mathrm{gm}$ up to $100 \mathrm{ml}$ YPG medium). In the first experiment, the five yeast strains were grown on YPG medium, with $0.5 \mathrm{M}$ or $1 \mathrm{M} \mathrm{NaCl}$ concentrations, separately, for 2 days at $30^{\circ} \mathrm{C}$ (normal growth temperature).

In another experiment, the yeast strains were put under the influence of $0.5 \mathrm{M}$ of $\mathrm{NaCl}$ for 24 hours, then in the next day, they were grown on 1 $\mathrm{M} \mathrm{NaCl}$ for another 24 hours at $30^{\circ} \mathrm{Caccording}$ to Logothetis et al (2007).

\section{Dilution plating}

This procedure was used to identify the number of viable micro-organisms (colonies) in a fixed amount of a liquid medium. It can also be fairly easily modified to give results with solid medium according to Jorgensen and Turnidge (2015) method.

To perform serial dilutions, a small amount of YPG (yeast extract, peptone, glucose and agar) medium was transferred into a new container to dilute the original solution. The diluted sample was then used as the base solution to make an additional dilution. This was carried out several times in a range of concentrations. The initial concentration with target range needed for a given assay determined the size and number of dilution steps required. Often, serial dilutions were performed; they were described as ratios of the original and final concentrations. Mixing $100 \mu \mathrm{l}$ of a stock solution with $900 \mu \mathrm{l}$ of water makes a 1:10 dilution. The final volume of the diluted sample was $1000 \mu \mathrm{l}(1$ $\mathrm{mL}$ ) and the concentration was $1 / 10$ that of the original solution. This was commonly referred to as a $10 x$ dilution. Five $\mu$ l was obtained from dilutions and put in Petri dishes; each experiment was made in 3 replicates for every strain.

\section{3- Statistical analysis}

The obtained data were statistically analyzed by using SPSS version 19.0 (Arbuckle, 2010) to compare of the mean duration of stress using analysis of variance (ANOVA) between the various treatment groups. This was performed using Dunnett test (Dunnett,1964).

\section{RESULTS AND DISCUSSION}

The results of heat and salt experiments appear in Table (2) and Figure (1). The five yeast strains showed different responses under heat or salt stresses compared with the control. Three 

or salt stress

replicates for each strain were applied for each treatment. Means of these replicates were calculated and differences were measured statistically.

\section{1- Effect of stresses on Yeast strains}

\section{1- Heat stress}

Heat stress results in Table (2) and Figure (1) showed that strain S4 was more tolerant at $40^{\circ} \mathrm{C}$ with insignificant difference compared to the control $\left(30^{\circ} \mathrm{C}\right)$, while, the same strain gave significant difference than the control at $20^{\circ} \mathrm{C}$ and confirmed that it was more tolerant at the two heat stress experiments. Strain S5 also was more tolerant at $20^{\circ} \mathrm{C}$ with insignificant difference compared to the control. The strains exposed to a temperature at $20^{\circ} \mathrm{C}$ or $40^{\circ} \mathrm{C}$ had a difference between the control $\left(30^{\circ} \mathrm{C}\right)$ were previously detected by Holubarova et al (2000) who exposed yeast cells at $41^{\circ} \mathrm{C}$ and found intolerance of yeast cells.

\section{2- Salt stress}

For salt experiments, (Table 2 and Figure1), four strains showed decrease in number of colonies with significant differences under all salt treatments when compared with the control. Strain S3 gave the only insignificant number of colonies (19 colony) when grown in medium with $0.5 \mathrm{M} \mathrm{NaCl}$ separately compared to the control (24 colony). The general mean of this work was to gain further understand of yeast fermentation performance as number of colonies under salt stress conditions, especially, work was focused on the evaluation of $\mathrm{NaCl}$ induced salt stress responses on industrial yeast strains (Saccharomyces cerevisiae).
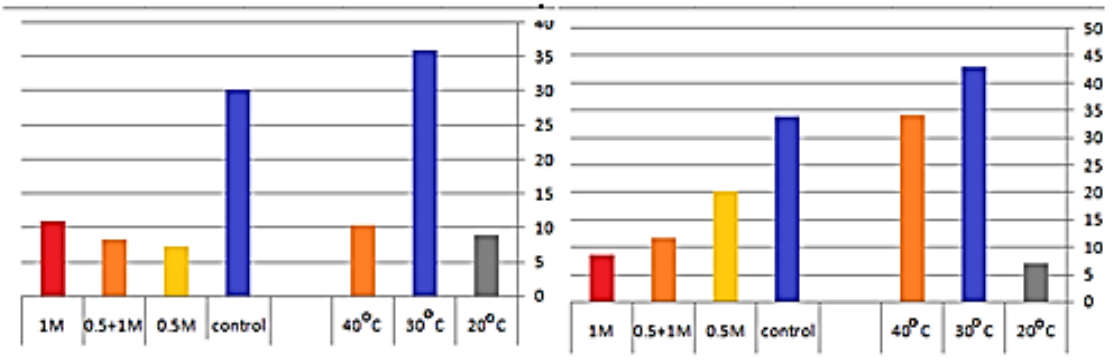

S1 strain

\$2 straln
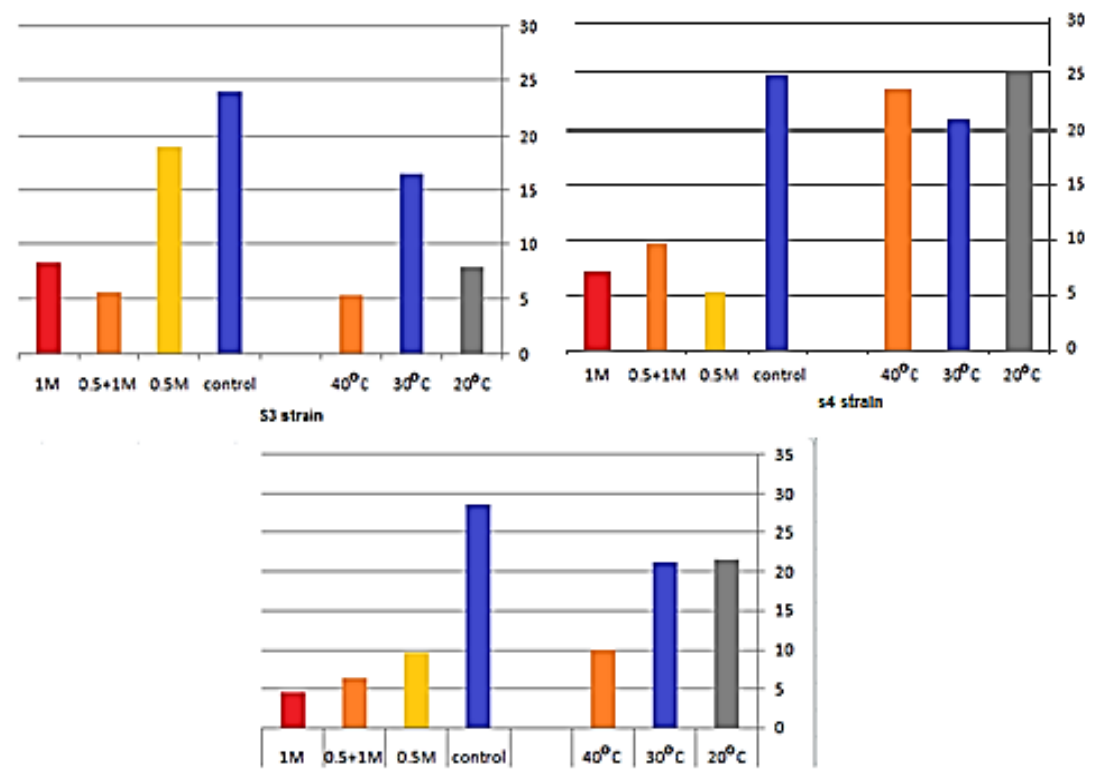

S5 strain

Fig. 1. Mean number of colonies that exposed to temperatures $20^{\circ} \mathrm{C}$ and $40^{\circ} \mathrm{C}$ and salinity at concentration $(0.5,0.5+1 \mathrm{M}$ and $1 \mathrm{M} \mathrm{NaCl})$ 
Table 2. Number of colonies forming units of Saccharomyces cerevisiae after exposure to heat or salt stresses compared with the control.

\begin{tabular}{|c|c|c|c|c|c|}
\hline \multirow{2}{*}{ Stress } & \multirow{2}{*}{ Treatments } & Rep 1 & Rep 2 & Rep 3 & Mean \\
\hline & & \multicolumn{4}{|c|}{ S1 } \\
\hline \multirow{3}{*}{ Heat stress } & $20^{\circ} \mathrm{C}$ & 11 & 9 & 7 & 9 \\
\hline & $30^{\circ} \mathrm{C}$ (cont.) & 34 & 35 & 39 & 36 \\
\hline & $40^{\circ} \mathrm{C}$ & 12 & 12 & 7 & $10.3^{*}$ \\
\hline \multirow{5}{*}{$\begin{array}{c}\text { Salt } \\
\text { stress } \\
(\mathrm{NaCl})\end{array}$} & Control & 32 & 28 & 31 & 30.3 \\
\hline & $0.5 \mathrm{M}$ & 7 & 5 & 10 & $7.3^{*}$ \\
\hline & $0.5+1 M$ & 5 & 12 & 8 & $8.3^{*}$ \\
\hline & $1 \mathrm{M}$ & 11 & 8 & 14 & $11^{*}$ \\
\hline & & \multicolumn{4}{|c|}{ S2 } \\
\hline \multirow{3}{*}{ Heat stress } & $20^{\circ} \mathrm{C}$ & 7 & 6 & 8 & 7 \\
\hline & $30^{\circ} \mathrm{C}$ (cont.) & 42 & 42 & 45 & 43 \\
\hline & $40^{\circ} \mathrm{C}$ & 34 & 33 & 36 & $34.3^{*}$ \\
\hline \multirow{5}{*}{$\begin{array}{c}\text { Salt } \\
\text { stress } \\
(\mathrm{NaCl})\end{array}$} & Control & 34 & 29 & 39 & 34 \\
\hline & $0.5 \mathrm{M}$ & 22 & 19 & 20 & $20.3^{*}$ \\
\hline & $0.5+1 M$ & 7 & 11 & 17 & $11.6^{*}$ \\
\hline & $1 \mathrm{M}$ & 5 & 8 & 13 & $8.6^{*}$ \\
\hline & & \multicolumn{4}{|c|}{ S3 } \\
\hline \multirow{3}{*}{ Heat stress } & $20^{\circ} \mathrm{C}$ & 7 & 10 & 7 & 8 \\
\hline & $30^{\circ} \mathrm{C}$ (cont.) & 19 & 15 & 16 & 16.6 \\
\hline & $40^{\circ} \mathrm{C}$ & 10 & 3 & 3 & $5.3^{*}$ \\
\hline \multirow{5}{*}{$\begin{array}{c}\text { Salt } \\
\text { stress } \\
(\mathrm{NaCl})\end{array}$} & Control & 20 & 24 & 28 & 24 \\
\hline & $0.5 \mathrm{M}$ & 14 & 28 & 15 & 19 \\
\hline & $0.5+1 M$ & 5 & 8 & 4 & $5.6^{*}$ \\
\hline & $1 \mathrm{M}$ & 8 & 11 & 6 & $8.3^{*}$ \\
\hline & & \multicolumn{4}{|c|}{ S4 } \\
\hline \multirow{3}{*}{ Heat stress } & $20^{\circ} \mathrm{C}$ & 23 & 27 & 26 & 25.3 \\
\hline & $30^{\circ} \mathrm{C}$ (cont.) & 20 & 23 & 21 & 21.3 \\
\hline & $40^{\circ} \mathrm{C}$ & 22 & 24 & 24 & 23.3 \\
\hline \multirow{5}{*}{$\begin{array}{c}\text { Salt } \\
\text { stress } \\
(\mathrm{NaCl})\end{array}$} & Control & 15 & 27 & 32 & 24.6 \\
\hline & $0.5 \mathrm{M}$ & 2 & 6 & 8 & $5.3^{*}$ \\
\hline & $0.5+1 M$ & 7 & 5 & 17 & $9.6^{*}$ \\
\hline & $1 \mathrm{M}$ & 10 & 6 & 6 & $7.3^{*}$ \\
\hline & & \multicolumn{4}{|c|}{ S5 } \\
\hline \multirow{3}{*}{ Heat stress } & $20^{\circ} \mathrm{C}$ & 26 & 21 & 18 & 21.6 \\
\hline & $30^{\circ} \mathrm{C}$ (cont.) & 20 & 21 & 23 & 21.3 \\
\hline & $40^{\circ} \mathrm{C}$ & 10 & 11 & 9 & $10^{*}$ \\
\hline \multirow{4}{*}{$\begin{array}{c}\text { Salt } \\
\text { stress } \\
(\mathrm{NaCl})\end{array}$} & Control & 23 & 36 & 27 & 28.6 \\
\hline & $0.5 \mathrm{M}$ & 10 & 7 & 12 & $9.6^{*}$ \\
\hline & $0.5+1 M$ & 2 & 8 & 9 & $6.3^{*}$ \\
\hline & $1 \mathrm{M}$ & 3 & 6 & 5 & $4.6^{*}$ \\
\hline
\end{tabular}

* = Significant differences for treatments compared with the control (Dunnett Test).

These results were confirmed by the previous findings of Wei et al (1982) who reported that the effect of high salt content on semisolid culture is essentially the same as the effect on liquid culture; i.e., as the salt content increased, the following occurred: (1) the growth of yeasts decreased, (2) the lag period of the yeast biomass curve lengthened, (3) the sugar intake was lowered, (4) the yield of ethanol was reduced.

Logothetis et al (2007) also, found that salt pre-treatments resulted in beneficial influences on both cell viability and fermentation performance of an industrial yeast strain.

\section{CONCLUSION}

Yeast strains showed different responses under heat and salt experiments when compared with the control. The detection of three strains tolerant to heat or salt stresses are a good trail that works may be completed on these strains to study molecular genetics effect at the level of protein and DNA.

\section{REFERENCES}

Arbuckle, J. L., 2010. IBM SPSS Amos 19 user's guide. Crawfordville, FL: Amos Development Corporation, $635 \mathrm{p}$.

Brion, C., Pflieger, D., Souali-Crespo, S., Friedrich, A., and Schacherer, J., 2016. Differences in environmental stress response among yeasts is consistent with species-specific lifestyles. Molecular Biology of the Cell, 27(10), 1694-1705.

Curran, B. P., and Bugeja, V., 2006. Basic investigations in Saccharomyces cerevisiae. In "Yeast Protocol", pp. 1-13. Humana Press, Totowa, New Jersey, USA.

Dunnett, C.W., 1964. New tables for multiple comparisons with a control, Biometrics, 20, 482-491.

Gasch, A.P., Spellman, P.T., Kao, C.M., CarmelHarel, O., Eisen M.B., Storz, G., Botstein, D. and Brown, P.O., 2000. Genomic expression programs in the response of yeast cells to environmental changes, Mol Biol Cell., 11, 42414257.

Holubarovaet, A., Muller, P. and Svoboda, A., 2000. A response of yeast cells to heat stress: cell viability and the stability of cytoskeletal structures. ScriptaMedica (BRNO), 73(6), 381392.

Jorgensen, J.H. and Turnidge, J.D., 2015. Susceptibility test methods: dilution and disk diffusion methods. In: "Manual of Clinical Microbiology, Eleventh Edition" pp.1253-1273. American Society of Microbiology.

Jozefczuk, S., Klie, S. Catchpole, G., Szymanski, J., Cuadros-Inostroza, A., Steinhauser, D., Selbig, J. and Willmitzer, L., 2010. Metabolomic and transcriptomic stress response of Escherichia coli. Mol System Biol., 6, 364, DOI 10.10.3.8./msb.2010.18.

Logothetis, S., Walker, G., and Nerantzis, E.T. 2007. Effect of salt hyperosmotic stress on 

or salt stress

yeast cell viability. Zbornik Matice Srpske Za prirodne Nauke, (113), 271-284.

Wei, C.J., Tanner, R.D. and Malaney, G. W., 1982. Effect of sodium chloride on bakers' yeast growing in gelatin. Applied and Environmental Microbiology, 43(4), 757-763.
Zhao, X. Q. and Bai, F. W., 2009. Mechanisms of yeast stress tolerance and its manipulation for efficient fuel ethanol production. Journal of Biotechnology, 144(1), 23-30. 



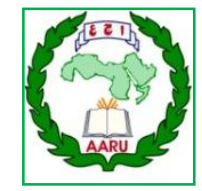

المؤتمر الرابع عشر لبحوث التنمية الزراعية، ومارية

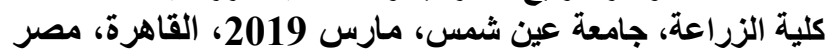

مجلا(27)، عدد (1)، عدد خاص مارس، مارس 2019

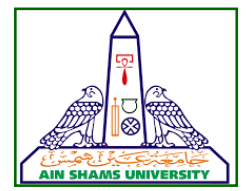

استنباط بعض سلالات الخميرة (ساكارومايسس سبريفسيا) المتحملة لإجهادى الملوحة والحرارة

[54]

سارة كمال عبد المقصود - لمياء محمد سيد - فاطمة محمد بدوي - إيمان محمود فهمى

قسم الوراثة- كلية الزراعة- جامعة عين شمس - ص.ب 68 - حدائق شبرا

“Corresponding author: sara_kamal2012@yahoo.com

Received 21 October, 2018,

Accepted 30 October, 2018

أجريت تجربة أخرى بتركيز قدره 0.5 مولر لمدة 24

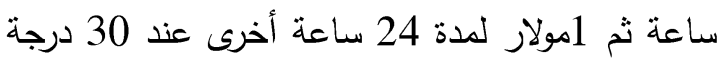
مئوية (درجة الحرارة الطبيعية لنمو السلالات) وذللك

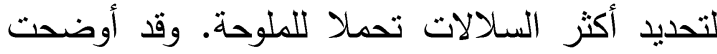

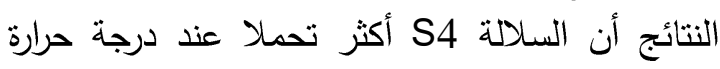

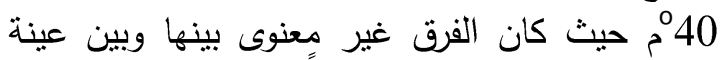

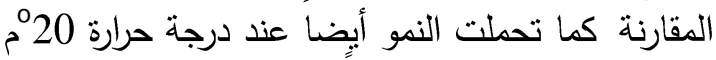

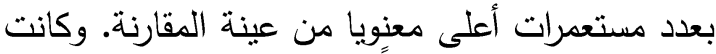

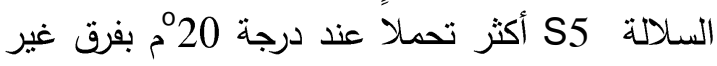
معنوي عن عينة المقارنة، وبالنسبة لتجربة تحمل تلاكل

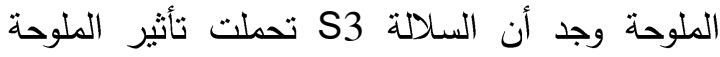
بتركيز 0.5 مولار من كلوريد الصوديوم بفرق غير تلير

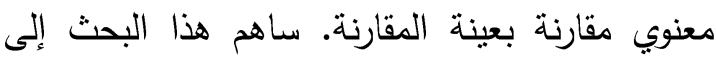

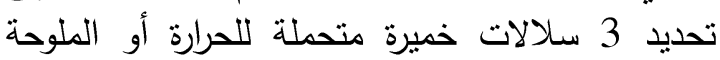
يمكن استخدامها فى الدراسات الوراثة الجزيئية.

الكلمات الدالة: الخميرة، سكاروميسيسسيرفسيا، التكيف، الإجهاد الاسموزي، الإجهاد الحراري.

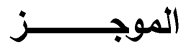

تتعرض جميع الكائنات الحية لظروف بيئية متغيرة يجب عليها التكيف معها، حيث يتم تعريف الإجهاد

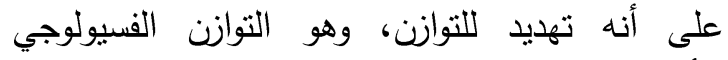

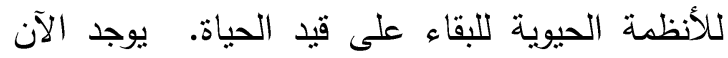

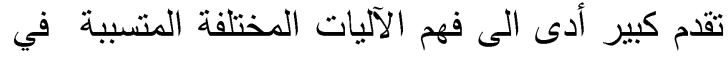

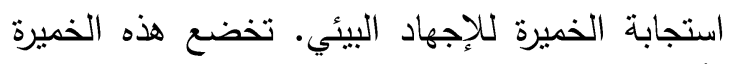

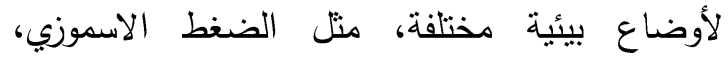

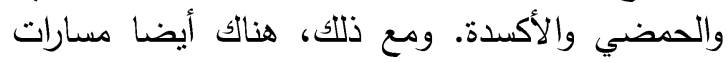

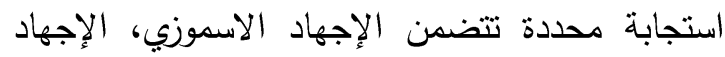
الحراري. تم تعريض خمس سلالات من الخميرة لضغوط مختلفة، من حيث تغيير درجة حرارة النموحيث تم تم تعريضها للنمو عند 20 درجة مئوية أو 40 درجة دئة دئة مئوية إلى جانِ تعريض عينة المقارنة عند 30 درجة مئوية. وقد تم أيضا تم تتمية السلالات في تركزين مختلفتين

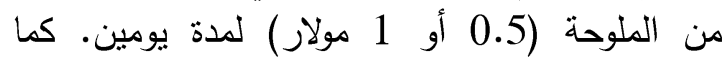

